\title{
Bertha and assisted dying
}

I am a retired London GP, and my brotherin-law, conductor and baroque violinist Derek Solomons had just sent me some old family pictures.

One of them is a charming small etching of a 14-year-old girl. She had a direct gaze and a neat bonnet perched on her back. Entitled Bertha it is by distinguished New Zealand artist Ernest Heber Thompson (1891-1971). Completed in 1926 when he was living in London, a fine example of the print run of 25 is in The Museum of New Zealand Te Papa Tongarewa in Wellington. Thompson was born in Dunedin, and after being badly wounded in World War I was sent to hospital in Brockenhurst to recover. An army scholarship enabled him to study at The Slade and The Royal College of Art.

Bertha by Ernest Heber Thompson, 1926. Museum of New Zealand Te Papa Tongarewa, Gift of the artist, 1959, Acc. no. 1959-24-4. Reproduced with permission from Pauline Mercier.
He then settled in London where he remained as painter, etcher, and teacher. $\mathrm{He}$ also represented The New Zealand National Gallery in London and was responsible for many important additions to the National Collection. The portrait is of my maternal aunt Bertha Stern. I was born in 1933 but have no recollection of ever actually meeting her.

I was passing through Wellington in 2010 and I contacted Tony Mackle, Collection Manager Prints and Drawings, to arrange a viewing and tell him about the tragic background to the picture. In February I was welcomed to The Museum by him and Victoria Robson, Curator of European Art, and was delighted to see a fine copy of the etching, one of 32 works by Thompson held there. There was a large archive with the piece, much of it provided by Pauline Mercier, daughter of the artist, and a brief note (committed suicide) about

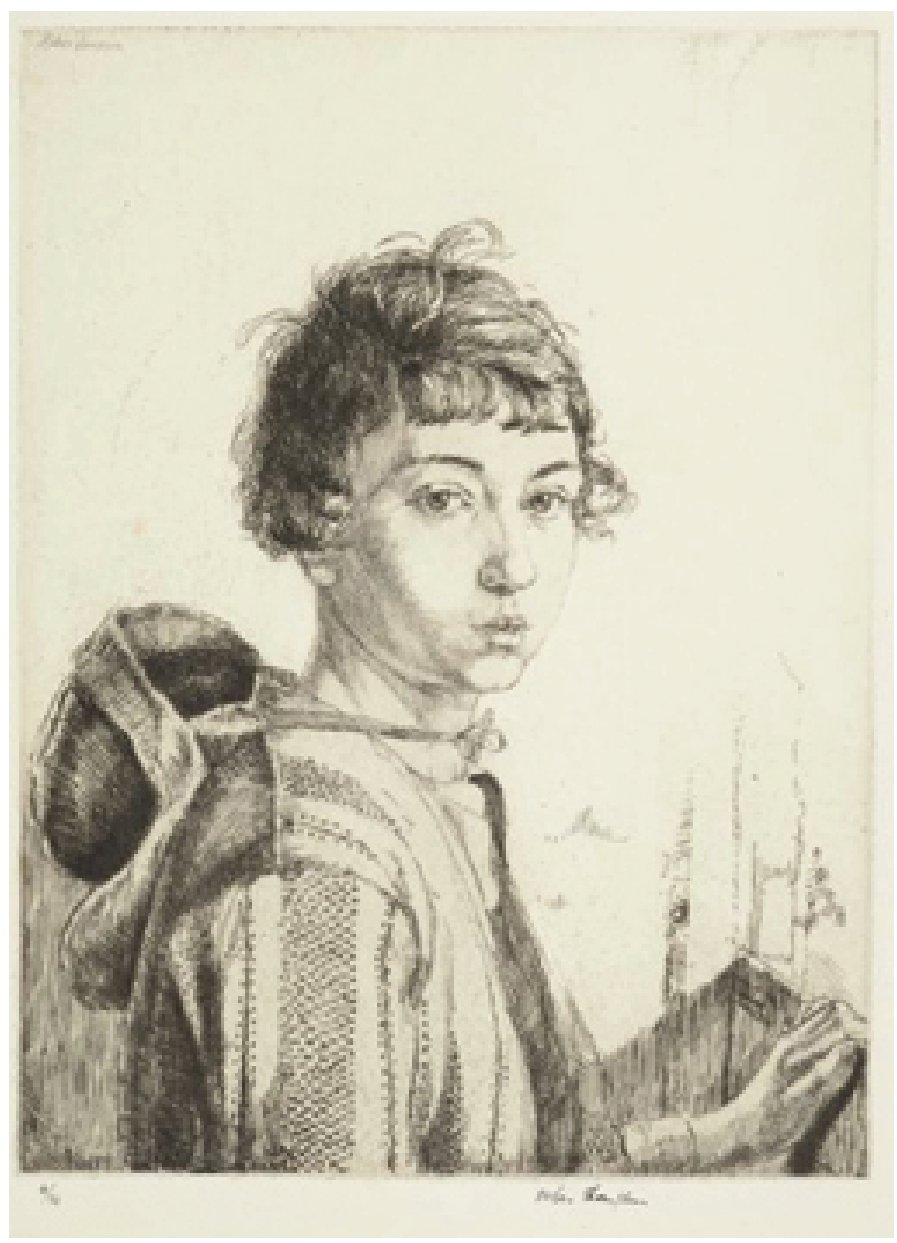

Jewish Socialist writing in the East End before World War II. His second novel Phineas Kahn, Portrait of an Immigrant, was published by Jonathan Cape in 1937 (his first novel, the explosive Jew Boy, first published in 1935, is about to be republished by London Books Classics). Phineas Khan is based on the story of my maternal grandfather Philip Stern, his escape from Tsarist Russia and long-term conscription as an army musician, ending up in London with his 10 children. Four of his grandchildren became doctors or dentists, one a diplomat and one even a Conservative MP. The last quarter of the book is largely devoted to the tragedy of Bertha and Michael, even using their real names.

This family tragedy had a profound effect on my father, who died in 2005 at the grand old age of 96 , still in harness as a columnist in The Stage - the British showbiz weekly.

The story of Bertha and Michael had been immortalised in print, but he went further. My sister's second name is Bertha. The story hit the newspapers and was even reported in 1936, by M Hamblin Smith, in the Journal of Mental Science ${ }^{1}$ as a case of 'Euthanasia and suicide'.

At the inquest the jury returned a verdict of murder against my aunt, but the foreman said 'to brand her as a murderess, when that young woman has acted so wonderfully bravely, and in such a self-sacrificing manner makes it really difficult for us. It is only that the laws of the land insist on the form of verdict. Otherwise, the word murder is horrible, and none of the jury would use such a word in such circumstances."

The coroner was reported as having spoken of the wife's 'wonderful act'. Smith described the law and practice of homicide and murder three-quarters of a century ago as chaotic.

2010 is a little different. The debate on assisted dying is ongoing.

\section{Eric Bloomfield}

\section{REFERENCE}

1. MH Smith. A case of euthanasia and suicide. J Ment Sci 1936; 82: 70-71.

law, was the founding father of 